\title{
A RARE CASE OF MALIGNANT ACROSPIROMA MASQUERADING AS SQUAMOUS CELL CARCINOMA OF SCALP
}

\author{
Falari Sanyam Santosh', Shrikiran K2, Mandrekar Sudip Datta³, Mondkar Sonali Dilip ${ }^{4}$
}

${ }_{1}^{1}$ Senior Resident, Department of General Surgery, Goa Medical College and Hospital.

2Junior Resident, Department of General Surgery, Goa Medical College and Hospital.

3Junior Resident, Department of General Surgery, Goa Medical College and Hospital.

${ }^{4}$ Senior Resident, Department of General Surgery, Goa Medical College and Hospital.

HOW TO CITE THIS ARTICLE: Santosh FS, Shrikiran K, Datta MS, et al. A rare case of malignant acrospiroma masquerading as squamous cell carcinoma of scalp. J. Evolution Med. Dent. Sci. 2018;7(08):1065-1066, DOI: 10.14260/jemds/2018/242

\section{PRESENTATION OF CASE}

A 55 years old man presented to our department with complaints of a swelling over scalp in midline for 5 years duration. Initially, it was small in size in the form of nodule, which has increased progressively to present size of $9 * 7 \mathrm{~cm}$ of scalp swelling. Patient is a carpenter by occupation and gave history of carrying heavy logs of wood over his head causing trivial trauma on a day-to-day basis. Over last one year, swelling started to ulcerate and fungate with foul smelling discharge.

On examination, there was a single ulceroproliferative swelling present over scalp in midline measuring $9 * 7.5 \mathrm{~cm}$ with rolled out everted edges with areas of proliferative granulating tissue intermingled with slough. Mass was firm in consistency, non-tender and appeared to be fixed to underlying skull bones. The surrounding skin showed multiple skin lesions in the form of satellite lesions. There was no evidence of palpable lymphadenopathy in this patient.

Acrospiroma represents a group of benign ductal tumours of the eccrine sweat glands that sometimes are connected to skin. Acrospiroma are also termed as clear cell, nodular, superficial and solid-cystic hidradenoma, clear cell myoepithelioma, porosyringoma, large sweat gland adenoma or basal cell carcinoma of sweat gland origin. These are generally benign lesions with few reports of malignant transformation. In our case, we report a 55 years old male with an ulceroproliferative swelling over scalp, clinically looking like squamous cell carcinoma, but histopathologically diagnosed as a malignant acrospiroma which was treated with wide local excision. A case of malignant acrospiroma is rarely reported and thus literature on their treatment therapy is limited.

\section{DIFFERENTIAL DIAGNOSES}

- Squamous cell carcinoma.

- Adenosquamous carcinoma.

- Hidradenocarcinoma.

- Amelanotic melanoma.

- Dermatofibroma.

'Financial or Other Competing Interest': None.

Submission 11-01-2018, Peer Review 04-02-2018,

Acceptance 12-02-2018, Published 19-02-2018.

Corresponding Author:

Falari Sanyam Santosh,

$G-3$, Querobino Apartments,

Altinho, Mapusa, Goa.

E-mail: falarisanyam@gmail.com

DOI: $10.14260 /$ jemds $/ 2018 / 242$

\section{CLINICAL DIAGNOSIS}

A clinical diagnosis of squamous cell carcinoma was made based on physical examination. CT scan of head showed hyperintense mass over scalp with arterial enhancement with multiple feeding vessels; underlying skull bones were intact and showed no evidence of infiltration.

Above patient underwent wide local excision and wound bed was kept open for it to granulate. Grossly, specimen showed features of cauliflower like growth with multiple areas of greyish-white nodules. Growth shows small cysts and papillary areas. On microscopy, multiple sections from growth revealed islands of basaloid cells separated by cystlike structure containing eosinophilic material. Cells showed moderate amount of cytoplasm with mild degree of pleomorphism and exhibiting low mitotic activity. Picture suggestive of malignant skin adnexal tumour- malignant acrospiroma. Margins of excision were free. Immunohistochemistry showed strong positivity for vimentin and negative staining for desmin.

Patient was put on a regular follow-up and defect area was grafted with split-thickness skin graft.

\section{PATHOLOGICAL DISCUSSION}

Malignant acrospiroma is a rare tumour of the eccrine sweat glands, that usually displays an aggressive behaviour. ${ }^{1}$ Disease tend to arise or transform from a previous benign lesion. ${ }^{1}$ They usually present as a slow growing tumour measuring 2 to $4 \mathrm{~cm}$ nodules in middle age or older individuals. Clinically, they masquerade as nodular cystic lesion or malignant melanoma. ${ }^{2}$ From our case study, it was noticed that constant trauma to skin and connective tissue can lead to transformation of benign adnexal tumour into malignant. This presentation of malignant acrospiroma over scalp is one of the rarest presentation and literature regarding management of such tumour is very limited.

Johnson and Hewig in 1969 first coined the term acrospiroma by histological and histochemical studies, as they mimic eccrine sweat gland. ${ }^{3}$ These lesions are classified according to location in layers of skin into epidermal, dermal and juxtaepidermal acrospiroma. ${ }^{4}$

In the present case, patient underwent wide local excision and postoperative follow-up did not show any evidence of recurrence and hence patient was not subjected to any form of chemotherapy or radiotherapy. 


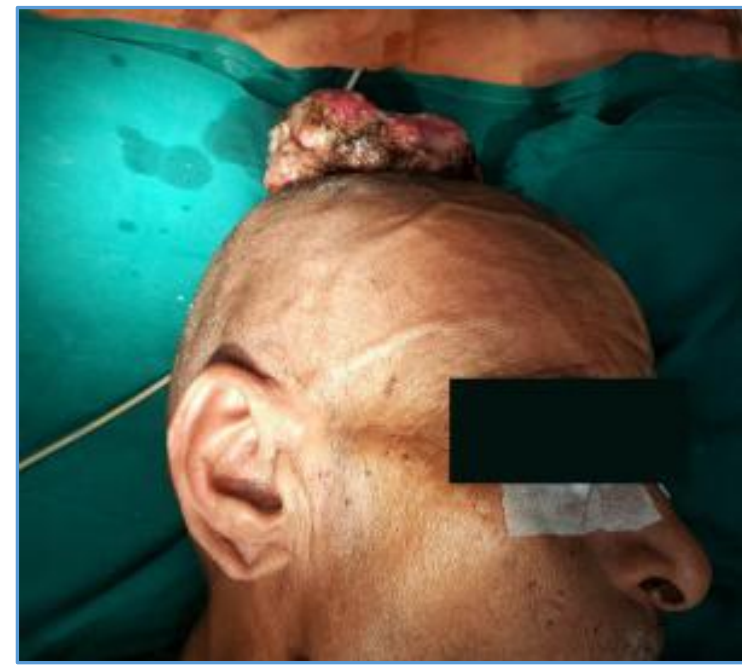

Malignant Acrospiroma Lateral View

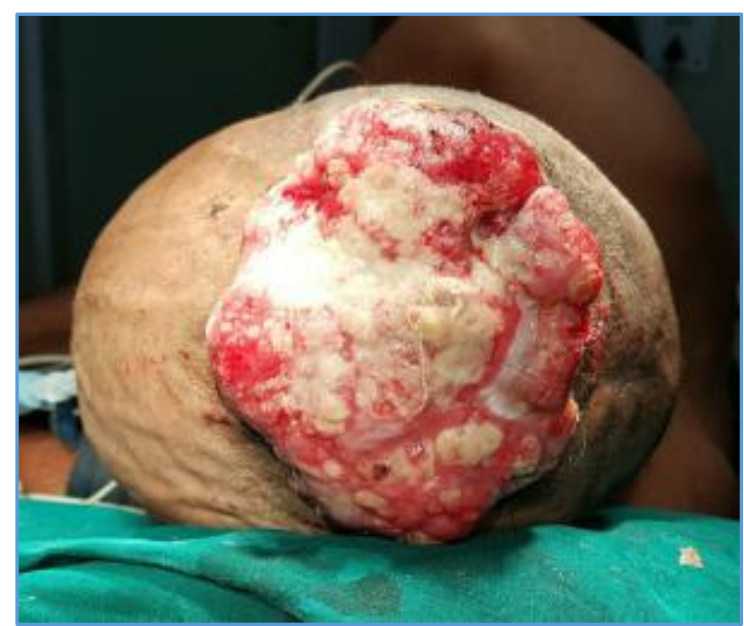

Malignant Acrospiroma Superior View

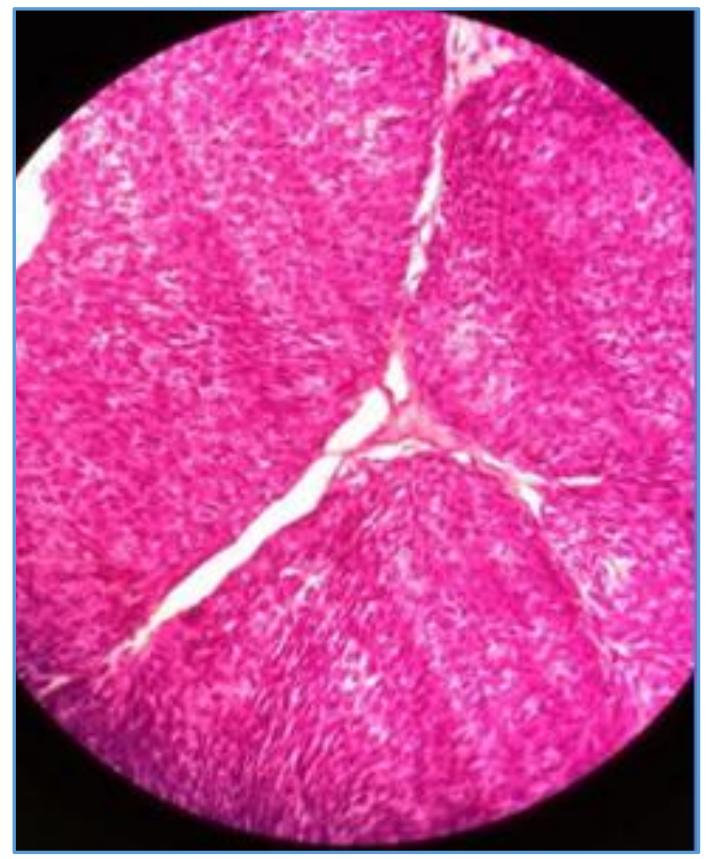

Microscopy View of Malignant Acrospiroma

\section{DISCUSSION OF MANAGEMENT}

Malignant acrospiroma are treated by wide local excision, but with local recurrence rate of around $50 \%$. In one case there was described use of wide local excision with adjuvant radiotherapy for malignant eccrine acrospiroma of scalp and left parotid, which eventually had local recurrence after 2 years. ${ }^{5}$

In another reported case, a 66 years old female with recurrent malignant acrospiroma of chest was resected and followed by reconstruction surgery and radiotherapy. There was no evidence of local recurrence or distant mets. ${ }^{6}$ The role of chemotherapy in eccrine sweat gland carcinoma and especially malignant acrospiroma is not clear. Various case studies have shown effect of cyclophosphamide, doxorubicin, bleomycin and cisplatin on malignant acrospiroma with partial response. ${ }^{7}$ The role of radiotherapy is well established. In one report of 3 patients who received adjuvant radiotherapy, 2 patients remained disease free at 27 and 35 months respectively and third died of rapid progressive systemic disease. 8 The dose of radiation was 70 gray for surgical bed and 50 gray for regional lymphatic chains. ${ }^{8}$ However, in our case patient was not subjected to any adjuvant therapy in the form of chemotherapy or radiotherapy, since wound was allowed to heal by granulation tissue formation followed by skin grafting. Hence, patient was not subjected to radiotherapy. On subsequent follow-up, patient did not show any evidence of recurrence or mets.

\section{FINAL DIAGNOSIS \\ Malignant Acrospiroma.}

\section{CONCLUSION}

Malignant acrospiroma are cutaneous neoplastic lesions arising from sweat gland and are very rare. They are often misdiagnosed with other skin lesions such as squamous cell carcinoma, malignant melanoma, osteomyelitis or benign skin nodule lesion. Wide local excision is the only treatment modality with established evidence of adjuvant radiotherapy.

\section{REFERENCES}

[1] Diab M, Gabali A, Kittaneh M, et al. Malignant acrospiroma: a case report in the era of next generation sequencing. BMC Cancer 2017;17(1):221.

[2] Wildemore JK, Lee JB, Humphreys TR. Mohs surgery for malignant eccrine neoplasms. Dermatol Surg 2004;30(12 Pt 2):1574-9.

[3] Johnson BL, Helwig EB. Eccrine Acrospiroma. A clinicopathologic study. Cancer 1969;23(3):641-57.

[4] Fletcher CD. Diagnostic histopathology of tumours. $3^{\text {rd }}$ edn. Philadelphia: Churchill Livingstone 2000: p. 1457-8.

[5] Holden B, Colome-Grimmer M, Savage C, et al. Malignant eccrine acrospiroma with metastasis to the parotid. Ear Nose Throat J 2002;81(5):352-5.

[6] Long WP, Dupin C, Levine EA. Recurrent malignant acrospiroma. Treatment by chest wall excision. Dermatol Surg 1998;24(8):908-12.

[7] Bandyopadhyay $\mathrm{Al}$, Das M, Jana S, et al. Malignant acrospiroma of chest and abdominal wall treated with chemotherapy. Indian J Dermatol 2013;58(3):241.

[8] Harari PM, Shimm DS, Bangert JL, et al. The role of radiotherapy in the treatment of malignant sweat gland neoplasms. Cancer 1990;65(8):1737-40. 